\title{
In Search of the Optimal Reconstruction Method after Total Gastrectomy. Is Roux-en-Y the Best? A Review of the Randomized Clinical Trials
}

\author{
Carmen Naum¹, Rodica Bîrlă',2, Daniel Cristian Marica ${ }^{2}$, S.Constantinoiu ${ }^{1,2}$ \\ ${ }^{1}$ Carol Davila University of Medicine and Pharmacy, Bucharest, Romania \\ ${ }^{2}$ General and Esophageal Surgery Department, Center of Excellence in Esophageal Surgery, Saint Mary Clinical Hospital, Bucharest, Romania
}

Corresponding author:

Rodica Birla, MD

General and Esophageal Surgery Department, Center of Excellence in Esophageal Surgery, Sf. Maria Clinical Hospital, Bucharest, Romania E-mail: birlarodica@ahoo.com

\section{Rezumat}

În căutarea metodei optime de reconstructie după gastrectomia totală. Este Roux-în-Y cea mai bună? Review al unor studii clinice randomizate

$\mathrm{Au}$ fost propuse numeroase proceduri, de reconstrucție, după gastrectomie cu scopul de a obține o morbiditate postoperatorie cât mai scăzută. Esojejunostomia Roux-in-Y este acceptată pe scară largă ca o metodă de reconstrucție standard datorită simplitătii sale şi a rezultatelor nutriționale satisfăcătoare. Construcția unui rezervor gastric şi menținerea duodenului în tranzit au fost propuse pentru a ameliora calitatea vieții pacienților cu cancer gastric. Scopul acestui studiu este de a evalua calitatea vieții pacienților cu diferite tipuri de reconstructie după gastrectomie totală.

Metode: S-a efectuat o căutare sistematică în literatura de specialitate în PubMed, Science Direct, Wiley Online, Springer Link, până la 1 decembrie 2019. Au fost incluse doar articole originale publicate în limba engleză. Calitatea vieții a fost măsurată folosind diferite instrumente. S-au evaluat aspectele postoperatorii de esofagită de reflux, sindromul dumping, ingestia alimentară şi statusul ponderal.

Rezultate: 15 studii au fost incluse în această cercetare. Au fost comparate trei tehnici de restabilire a continuității tractului digestiv: eso-jejunostomia Roux-în-Y, interpozitia jejunală şi construcția unui rezervor gastric. S-au evaluat rezultatele statistice ale studiilor incluse, în ceea ce priveşte calitatea vieții şi statusul ponderal.

Concluzii: Lungimea ansei alimentare pentru profilaxia refluxului esojejunal trebuie să fie de minim $50 \mathrm{~cm}$, dar nu mai mare de $60 \mathrm{~cm}$ pentru prevenirea malabsorbției. Calitatea vieții a fost semnificativ 
îmbunătățită la pacienții la care s-a utilizat rezervorul gastric. Menținerea tranzitului duodenal nu pare sa aducă niciun beneficiu în calitatea vieții, sau statusul ponderal, chiar dacă aceasta este o cale fiziologică.

Cuvinte cheie: reconstrucție după gastrectomie totală, pouch, interpoziție jejunală, calitatea vieții postgastrectomie totală

\section{Abstract}

Background: Numerous procedures for reconstruction after total gastrectomy have been proposed in order to achieve the lowest postoperative morbidity. Roux-en-Y esojejunostomy is widely accepted as a standard reconstruction technique due to its simplicity and its satisfactory nutritional outcomes. The construction of a gastric pouch and the maintenance of the duodenal transit have been proposed to ameliorate the quality of life of patients with gastric cancer. The aim of this study is to assess the quality of life of patients with different types of reconstruction after total gastrectomy. Material and Method: A systematic literature search was performed in PubMed, Science Direct, Wiley Online, Springer Link, up to December 1, 2019. Only original articles published in English were included. Quality of life was measured using different instruments. Postoperative aspects of reflux oesophagitis, dumping syndrome, food intake and weight status were evaluated.

Results: 15 studies were included in this research. Three techniques for restoring the digestive tract continuity were compared: Roux-en-Y eso-jejunostomy, jejunal interposition and gastric pouch construction. The statistical results of the included studies were evaluated in terms of quality of life or weight status.

Conclusions: The length of the alimentary limb for prophylaxis of eso-jejunal reflux should be at least $50 \mathrm{~cm}$, but not more than $60 \mathrm{~cm}$ for the prevention of malabsorption. The quality of life was significantly better in patients with gastric pouch. Maintaining the duodenal transit does not seem to bring any benefit in quality of life or weight status, even if this is a physiological way.

Key words: Roux-an-Y, pouch, jejunal interposition, gastrectomy quality of life

\section{Introduction}

Gastric cancer has been described since 3000 $\mathrm{BC}$ in hieroglyphic inscriptions and papyrus manuscripts from ancient Egypt. The first statistical analysis of cancer incidence and lethality showed that the frequency and mortality through gastric cancer were the highest. Subsequently, it remained one of the most important malignant diseases, with significant differences in geographical, ethnic and socioeconomic distribution (1).

Currently, gastric cancer is the 5th most common cancer and the third mortal cancer worldwide, with 783,000 deaths estimated in 2018 and is considered a disease with a reserved prognosis especially in developing countries because of the diagnosis of the disease in advanced stages (2).

Although there has been an important progress in the treatment of stomach cancer in the recent years, surgical resection remains the treatment of choice for gastric cancer, which may require a total or subtotal gastrectomy depending on location and extent of the tumor (3).

The technique of reconstruction after gastrectomy for gastric cancer is still a debatable topic, the best method should keep postoperative morbidity as low as possible and to provide the best results at distance in terms of quality of life, too (3). 
According to the Japanese guides, there are two types of reconstruction: those with preservation of the duodenal passage and those without maintaining the duodenal passage. The most known in the group of surgeries excluding the duodenal passage are: the simple Roux-en-Y procedure and the one with the construction of a reservoir. In the duodenal passage preservation group, jejunal interposition with and without the formation of a reservoir is the most common (4).

Worldwide, Roux-en-Y eso-jejunostomy is the most common reconstruction procedure after gastrectomy due to its simplicity and satisfactory nutritional outcomes (5).

The construction of a gastric reservoir has been proposed to get better the quality of life of patients with total gastrectomy, to prevent malabsorption and weight loss (6).

The purpose of this study is to evaluate the quality of life of patients with different types of reconstruction after total gastrectomy by conducting a systematic research in the specialized literature.

\section{Material and Method}

\section{Strategy for Selecting Data from the Literature}

A systematic literature search was performed in PubMed, Science Direct, Wiley Online, Springer Link. In each database, the following terms were considered as keywords: "gastrectomy reconstruction", "total gastrectomy", "pouch", "jejunal interposition", "gastrectomy quality of life".

All articles were carefully analyzed to find relevant literature data, including abstracts, studies, and references.

\section{Selection of Articles}

The eligibility criteria (Table 1) included original studies that aimed to assess the quality of life in patients with total gastrectomy for gastric cancer.

Studies were excluded if they met any of the following criteria: studies such as reviews, comments, letters, case series performed on less than ten patients, studies published in other language than English, studies that did not study the quality of life of patients with total gastrectomy.

There were identified 1584 potentially relevant studies. After reviewing 360 full-text articles, 345 were excluded for various reasons (Fig. 1). 15 studies were included.

\section{Instruments for Assessing the Quality of Life}

The quality of life was measured using different instruments. Currently, the tools most commonly used to measure quality of life are self-administered questionnaires, as patients themselves are the most appropriate source of information. These instruments must meet three methodological criteria: reliability, validity and responsibility (7) (Table 2).

\section{Results}

Articles that proposed to evaluate the quality of life of patients with different types of reconstruction after total gastrectomy between 1987-2019 were included in the study.

All patients included in the study were treated by total gastrectomy. From the histopathological point of view, most of the tumors were adenocarcinomas.

Table 1. Eligibility criteria

\begin{tabular}{lll}
\hline Criterion & Inclusion & Exclusion \\
\hline Publication & $1987-2019$ English & $\begin{array}{l}\text { Before 1987 and after 2019 } \\
\text { Other language than English }\end{array}$ \\
\hline Article design & Original articles & Clinical studies as reviews \\
\hline Number of patients & Over 10 & Less than 10 \\
\hline Treatment & Open or laparoscopic total gastrectomy, & Other types of surgery \\
& with curative intent & \\
\hline
\end{tabular}




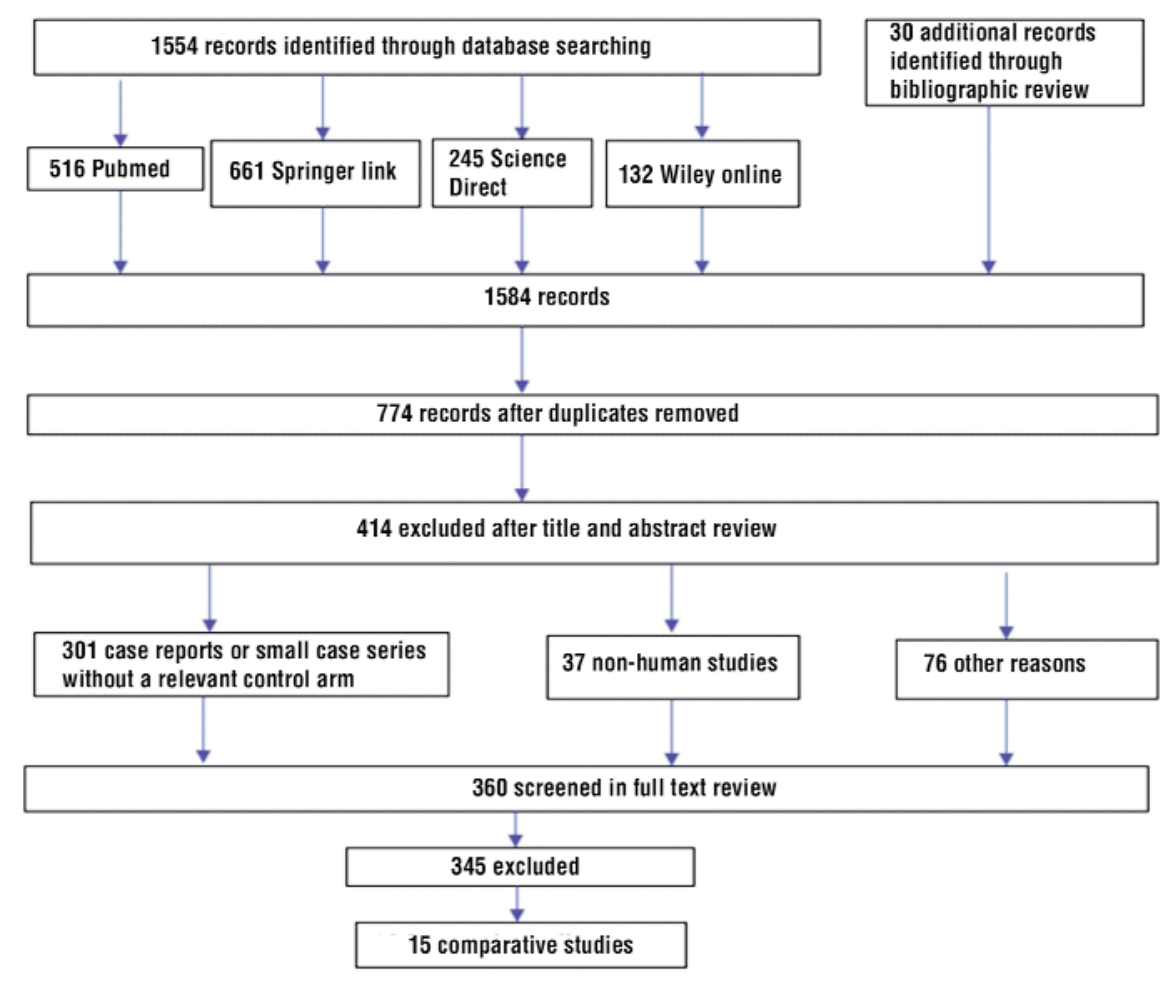

Figure 1. Criteria for the selection of articles

Table 2. Characteristics of the instruments used to measure the quality of life

\begin{tabular}{|c|c|c|c|}
\hline Instrument & Format & Content & Addressability \\
\hline $\begin{array}{l}\text { EORTC QLQ-C30 } \\
\text { and STO-22 }\end{array}$ & $\begin{array}{l}\text { Self-administered questionnaire } \\
\text { with } 22 \text { questions. Used with the } \\
\text { EORTC QLQ-C30 basic questionnaire } \\
\text { (30 questions). It is divided into five } \\
\text { scales and four unique questions [8]. }\end{array}$ & $\begin{array}{l}\text { - dysphagia } \\
\text { - pain } \\
\text { - reflux } \\
\text { - digestion } \\
\text { - anxiety } \\
\text { - taste } \\
\text { - hair loss } \\
\text { - dry mouth }\end{array}$ & specific for gastric cancer \\
\hline GIQLI & $\begin{array}{l}\text { Self-administered questionnaire with } \\
36 \text { specific and general questions. It } \\
\text { is divided into five areas [9]. }\end{array}$ & $\begin{array}{l}\text { - psychological } \\
\text { - social } \\
\text { - disease-specific }\end{array}$ & gastrointestinal diseases \\
\hline GSRS & $\begin{array}{l}\text { Self-administered questionnaire with } \\
15 \text { questions. It is divided into five } \\
\text { groups of symptoms [9]. }\end{array}$ & $\begin{array}{l}\text { - reflux } \\
\text { - abdominal pain } \\
\text { - indigestion } \\
\text { - diarrhea } \\
\text { - constipation }\end{array}$ & gastrointestinal diseases \\
\hline Spitzer index & $\begin{array}{l}\text { Self-administered questionnaire } \\
\text { with } 5 \text { dimensions for quality of life } \\
\text { assessment [9]. }\end{array}$ & $\begin{array}{l}\text { - activity level } \\
\text { - daily living } \\
\text { - health } \\
\text { - family and friends support } \\
\text { - perspectives }\end{array}$ & $\begin{array}{l}\text { cancer and other chronic } \\
\text { diseases }\end{array}$ \\
\hline Scorul Visick & $\begin{array}{l}\text { Self-administered questionnaire to note } \\
\text { the effect of surgery on symptomatology [10]. }\end{array}$ & $\begin{array}{l}\text { - complete resolution (grade I) } \\
\text { - improvement (grade II) } \\
\text { - no effect of surgery (grade III) } \\
\text { - deterioration (grade IV) }\end{array}$ & gastrointestinal diseases \\
\hline
\end{tabular}


The reconstructive procedures after total gastrectomy could be classed as: procedures with restoring intestinal continuity without preservation of the duodenal passage (Rouxin-Y eso-jejunostomy) and procedures with restoring intestinal continuity with preservation of the duodenal passage (jejunal interposition). These operations could be combined with the construction of a gastric "pouch" or "reservoir" (Roux-en-Y with pouch or jejunal interposition with pouch) (Table 3).

The size of groups was between 16 and 138 patients.13 studies had less than 100 patients. Only randomized clinical trials were included. The total follow-up period varied considerably, ranging from 6 months to 5 years. There have been made comparisons between various procedures of reconstruction of the digestive tract.

Simple Roux-en-Y was compared with Roux-en-Y with reservoir in 7 studies and with jejunal interposition in two studies. The three reconstructive procedures were compared in 3 studies. Comparing the quality of life between studies was difficult, as six types of indicators were used (Visick, Spitzer, QLQ-C30, GSRS (Gastrointestinal Symptom
Rating Scale), Cushieri and institutional questionnaires). The QLQ-C30 questionnaire was used in 4 studies (18,22,23,25), GSRS questionnaire in two studies $(17,19)$, Cushieri questionnaire (15) in one study, and nonstandardizated questionnaires in 6 studies $(11,14,16,20,21,24)$. The quality of life was assessed with the Visick scale in a single study (13).

\section{Reflux Esophagitis}

In our study only in 5 articles was analyzed, by endoscopy, the presence of reflux during the follow-up period $(12,15,19,17,23)$. There were no signs of reflux oesophagitis at 3 years after surgery $(15,19,23)$. In the rest of studies, no symptoms associated with reflux were mentioned. Other authors considered that the evaluation of esophago-jejunal reflux is not a criterion for assessing the quality of life.

\section{Dumping Syndrome}

The presence of dumping was analyzed in 4 studies $(12,13,20,23)$. No patient reported

Table 3. Selected articles

\begin{tabular}{|c|c|c|c|c|c|c|}
\hline Study & Year & Type of reconstruction & $\begin{array}{l}\text { Quality } \\
\text { of life }\end{array}$ & $\begin{array}{l}\text { Instruments for measuring } \\
\text { the quality of life }\end{array}$ & $\begin{array}{l}\text { Weight } \\
\text { status }\end{array}$ & Results \\
\hline Troidl [11] & 1987 & Y+reservoir /eso-jejunostomy & $S$ & Instiutional questionnaire & $S$ & $Y+$ reservoir \\
\hline Nakane [12] & 1995 & $\mathrm{Y} / \mathrm{Y}+$ reservoir/ interpos + reservoir & NS & No questionnaire & $S$ & $Y+$ reservoir \\
\hline Fuchs [13] & 1995 & Y+reservoir/ interpos + reservoir & NS & Visick scale and Spitzer index & NS & \\
\hline Schwarz [14] & 1996 & Y / Y+Reservoir /interpos & NS & Instiutional questionnaire & NS & \\
\hline livonen [15] & 2000 & $Y / Y+$ reservoir & $S$ & Cushieri & NS & $Y+$ reservoir \\
\hline Nozoe [16] & 2000 & $Y / Y+$ reservoir & $S$ & Instiutional questionnaire & S & $Y+$ reservoir \\
\hline Miyoshi [17] & 2001 & $Y / Y+$ reservoir & $S$ & GSRS & NS & $Y+$ reservoir \\
\hline Hoksch [18] & 2002 & Interpos + reservoir/interpos & $S$ & QLQ-C30 questionnaire & NS & $\begin{array}{l}\text { interpos+ } \\
\text { reservoir }\end{array}$ \\
\hline Kono [19] & 2003 & $\mathrm{Y} / \mathrm{Y}+$ reservoir & $S$ & GSRS & $S$ & $Y+$ reservoir \\
\hline Adachi [20] & 2003 & $Y / Y+$ reservoir /interpos + reservoir & $S$ & Instiutional questionnaire & S & $Y+$ reservoir \\
\hline Ishigami [21] & 2011 & $Y$ /interpos & NS & Institutional questionnaire & NS & \\
\hline Ito [21] & 2015 & $Y / Y+$ reservoir & NS & QLQ-C30 questionnaire & NS & \\
\hline Zonca [22] & 2016 & $Y / Y+$ reservoir & S & QLQ-C30 questionnaire & - & $Y+$ reservoir \\
\hline $\begin{array}{l}\text { Seung } \\
\text { MooNoh [23] }\end{array}$ & 2017 & Y /interpos & NS & Institutional questionnaire & NS & \\
\hline Tanaka [24] & 2018 & $\mathrm{Y} / \mathrm{Y}+$ reservoir & NS & QLQ-C30 questionnaire & NS & \\
\hline
\end{tabular}

S - statistically significant, NS - not statistically significant 
dumping 2 years after surgery in Nakane's study. Ivoven showed that dumping was more frequent in the Roux-in-Y group compared to the pouch group at 6 and 15 months after the operation. Analyzing results obtained by scintigraphy, Zonca found that dumping was more frequent in the Roux$^{-} e{ }^{-} Y$ group compared to the pouch group. In Fuchs study, 2 of 53 patients with Roux-en-Y reconstruction had symptoms associated with dumping compared to none of 53 patients with jejunal interposition. Patients undergoing Roux-en-Y reconstruction showed higher percentages of dumping compared to the pouch group (20)

\section{Number of Meals and Volume of Ingested Food}

Some authors noted that in the first six months postoperatively, at patients with total gastrectomy food intake was reduced to less than half the values before the operation.79\% of the patients in the pouch group were able to eat normal sized meals, compared with $14 \%$ of the patients in the Roux-en-Y group (15).

The quality of life was statistically significant in 8 studies $(11,15,16,17,18,19,20,23)$ and statistically insignificant in 7 studies $(12,13$, 14,21,22,24,25). Pouch Roux-en-Y was compared to simple esojejunostomy in 11 studies $(11,12,14,15,16,17,19,20,22,23,25)$. In studies that analyzed the pouch Roux-en-Y compared to simple esojejunostomy there was a better quality of life in 7 studies $(11,15,16,17,18,19$, $20,23)$, and in 4 studies $(12,13,22,25)$ no significant differences were found. In the group that compared Roux-in-Y reconstruction with interposition, there were significant differences in one study (19) in favor of Rouxin $-Y$ reconstruction, and in 4 studies $(12,14$, $21,24)$ there were no differences.

Weight gain was statistically significant in 5 studies $(11,12,16,19,20)$ and statistically insignificant in 9 studies $(13,14,15,17,18$, $21,22,24,25)$.

5 studies $(11,12,16,19,20)$ reported a significant weight gain in the pouch group compared to simple eso-jejunostomy, and no differences were found in 5 studies $(14,15,17$,
$22,25)$. In the group that compared the Rouxen-Y with the jujunal interposition, only two study $(12,20)$ reported a significant weight gain, while 5 studies $(13,18,21,24)$ found no significant differences.

\section{Discussions}

\section{Quality of life}

The concept of quality of life has been widely discussed in the literature. The World Health Organization has defined the quality of life as "each person's understanding of their own position in life in the context of the education and value systems in which they live and in relation to their purposes, expectations, standards and concerns" (26).

Quality of life assessment actually is a major concern even for surgeons. The new trends are specifically aimed for oncological surgery, where particular attention must be paid to the outcome of the surgical treatment. Maintaining or improving the quality of life is not only a trend, but one of the main goals for those involved in the treatment of cancer patients. Cancer treatment affects the physical, emotional and social status of the patients. A "physiological surgery" as much as possible of the organs or functions, as possible, is one of the means of improving the quality of life of cancer patients. For each specific organ, the effect of surgical excision on quality of life is variable and needs to be approached specifically. Gastric cancer offers a wide range of quality of life issues. These are not only related to the loss of the stomach but also the loss of the related function (27).

Technological progress has improved the results of gastric surgery, assisting the surgeon to recreate the physiological state of the digestive process in those patients undergoing gastric resection. The surgeon is the one who has to deal with the functional results that are sometimes complex. These range from weight loss to anorexia, anemia, diarrhea and delayed reintegration into socio-professional life. An important issue is the nutritional aspect: intake, digestion and absorption are problems 
caused by gastrectomy as well as the reconstruction procedure (27).

Food intake is limited due to loss of storage function, digestion and absorption are greatly reduced and only a small percentage of patients return to body weight during the period before surgery. (6)

After the total gastrectomy, the patients have an initial deterioration in most scales that measure the quality of life, but which gradually recover during 3-6 months after the operation (7).

It is very important to find an optimal type of reconstruction that can offer the highest quality of life with an optimum weight status and, at the same time, to minimize postoperative morbidities. Although over 70 different methods of gastrectomy reconstruction have been described, there is still no unitary opinion regarding the best technique after gastrectomy that would improve digestive function and quality of life. (27).

Quality of life was measured using different tools and reported in various ways. Currently, the instruments most commonly used to measure quality of life are selfadministered questionnaires, because the patient himself is the most appropriate source of information about his own quality of life. These instruments must meet 3 methodological conditions: reliability, validity and responsiveness and are divided into generic, symptom-related and cancer-specific (7).

According to studies in the literature, the most appropriate instrument for evaluating the quality of life of gastrectomised patients for gastric malignancies is the "Quality of Life Index" described by Eypasch. Unlike instruments that refer to a single dimension as the Cuschieri score for gastrointestinal symptoms and the non-specific instruments for the overall health assessment of cancer patients, such as the this validated questionnaire properly presents the multidimensional concept of quality of life by assessing symptoms and physical, emotional and social function (28).

The GIQLI index proved to be superior to the European Organization for Cancer
Research and Treatment EORTC QLQ-C30 index, which was developed specifically to estimate the quality of life in patients with gastrointestinal diseases and especially those undergoing surgical treatment (28).

EORTC QLQ-C30, is specific for cancer patients, includes 5 functional scales (physical, occupational role, emotional, cognitive and social), 3 symptom scales (fatigue, pain, nausea/vomiting) and a scale for considering the general condition of quality of life, plus 5 unique questions related to specific symptoms (dyspnoea, loss of appetite, sleep disorders, constipation and diarrhea). The response categories comprise four categories: "not at all", "little", "quite" or "very much" or as a modified visual analogue scale, from 1 to 7 (30).

STO22, is a module for QOL assessment for gastric cancer and focuses in particular on gastric cancer symptoms and side effects. It includes 22 elements that form five scales (dysphagia, pain and discomfort in the abdominal area, dietary restrictions, upper gastrointestinal symptoms and specific emotional problems) and four unique items (dry mouth, two questions about hair loss and body image) (7). Supporters of this measure instrument consider that quality of life is one of the main parameters to be evaluated in studies of gastric cancer surgery outcomes and this is achieved with specific measuring instruments (7).

\section{The Importance of Choosing the Reconstruction Procedure for the Quality of Life}

\section{Advantages of the jejunal pouch}

The construction of the pouch was designed to provide a gastric replacement. The pouch should lead to improved quality of life, allow higher food intake at a meal and help to prevent malabsorption and weight loss (7).

The importance of the gastric pouch is difficult to assess. Many studies have reported the benefits of using the jejunal pouch. Troidl and colleagues were the first to evaluate the benefit of using the pouch after total gastrectomy. They compared two 
procedures for restoring digestive tract continuity without preserving the duodenal passage: Roux-in-Y with reservoir and simple eso-jejunostomy. For patients with a survival for more than 1 year, they reported a better quality of life in the case of the reservoir (11). Nakane also confirmed the benefits of using the jejunal reservoir (12). Schwarz's study, although using an individual quality of life assessment system, which was not described in detail, showed an improvement in quality of life after pouch construction compared to simple Roux-in-Y reconstruction (14). Iivonen and colleagues compared two reconstructive procedures: simple Roux-in-Y and the construction of a jejunal reservoir and recommended that reconstruction after total gastrectomy must be in form of a jejunal pouch (15). They reported a better quality of life in the case of use the pouch at 5 years after the operation compared to the reconstruction without a pouch (16). Kono found a better quality of life and a lower incidence of biliary reflux in the jejunal reservoir compared to simple Roux-in-Y reconstruction (19). Adachi's study compared long-term results after three reconstruction methodes: Roux-en-Y, Roux-en$\mathrm{Y}$ with reservoir, and jejunal interposition. The pouch was superior to Roux-en-Y reconstruction in terms of postoperative quality of life (20). Zonca was of the same opinion in his study (23).

On the other hand, in some studies it was not possible to identify any benefit in using the pouch. Also, Ito and co-workers failed to demonstrate the benefits of using the gastric pouch in terms of quality of life at 12 months after surgery (22).

The short-term effect of pouch reconstruction has been favorable in some randomized studies $(16,19)$. These studies indicate that the jejunal pouch functions as a gastric reservoir and contributes to improved postoperative nutritional status compared to simple Roux-in-Y reconstruction (29).

Other studies demonstrated that digestive capacity increases over time in all types of reconstructions and any difference between procedures tends to disappear in the long term (19,31).

\section{Mantaining the duodenum in transit}

Mantaining the duodenum in transit presents more theoretical nutritional advantages. Any process that by-pass the duodenum results in a massive release of postprandial enteroglucagon that causes delayed carbohydrate absorption, but does not stop it.

The preservation of the duodenum allows the alimentary bolus to mix with the biliopancreatic secretions and guarantees a fibroscopic access to the duodenum. Restoration of digestive continuity by jejunal interposition between the esophagus and duodenum appears to be more physiological than the

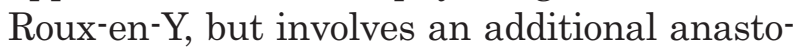
mosis (33) and presents a higher risk of biliary reflux (34). The Roux reconstruction has better results than the jejunal interposition in replacing the reservoir function, without producing early satiety (34).

In other study, Fuchs used the Visick score and the Spitzer index and found no significant difference in terms of quality of life between jejunal interposition with pouch and Roux-in$\mathrm{Y}$ reconstruction (13). The same conclusion was reached by Ishigami, who compared jejunal interposition with Roux-in-Y reconstruction. He pointed out that in the long term, nutrition status and quality of life were equalized between the two groups (21).

Nakane compared the Roux-in-Y reconstruction with or without a reservoir to jejunal interposition with pouch. After two years of follow-up, no significant advantage was reported for keeping the duodenum in transit (28).

\section{The importance of length of the alimentary limb of Roux-en-Y}

Alkaline reflux esophagitis is a post-operative complication that may occur after total gastrectomy, and its incidence depends on the type of reconstructive surgery. From this point of view, Roux-en-Y esophago-jejunostomy is the preferred method of reconstruction, because it is followed by a lower rate of alkaline esophagitis compared to other procedures 
(simple esophagojejunostomy, esophagoduodenostomy) (35-38), considered by some authors a method of preventing alkaline reflux in the esophagus (39).

Jejunal reflux into the esophagus may be accompanied by reflux symptoms: retrosternal pain, regurgitation and/or bitter taste. Reflux can be evaluated by scintigraphic methods, bilimetry (measurement of bilirubin concentration in the esophagus) and monitoring of 24-hour intraesophageal $\mathrm{pH}$ (Holter) to confirm the presence of alkaline $\mathrm{pH}$ in the esophagus (40). Alkaline reflux esophagitis, a complication of jejunoesophageal reflux, consists of inflammatory mucosal lesions. There are few studies that analyze endoscopic aspects of alkaline reflux esophagitis, these include a relatively small number of patients, and the reported results are variable $(41,42)$.

The variability of the incidence of alkaline reflux oesophagitis after Roux-en-Y may depend on the surgical technique and especially on the length of the jejunal limb, which should be after some authors at least 35 cm (preferably over $50 \mathrm{~cm})(40,41)$.

The most appropriate dimensions of alimentary and biliopancreatic limbs in the Roux-in-Y reconstructions remain unclear. The dimensions of the alimentary loop vary from 50 to $150 \mathrm{~cm}$ and for the biliopancreatic limb from 20 to $120 \mathrm{~cm}$. $(43,44)$

Many studies have shown that the problem of reflux is strongly associated with a short food intake - below $20 \mathrm{~cm}$, and when it is too long - over $60 \mathrm{~cm}$, problems of absorption and metabolism appear. (45)

\section{Body Weight}

Weight loss and malnutrition are also common problems after total gastrectomy leading to diminished postoperative quality of life. These can be explained by the reduced food intake as a result of the loss of stomach function (46)

Weight loss after total gastrectomy usually extended during the first year after surgery and most patients do not regain weight before surgery. Recent studies have shown that the quality of postoperative life is closely related to weight loss and the presence of a reservoir after total gastrectomy results in increased postoperative body weight. (32)

In other studies, no significant differences in weight were observed in the pouch group compared to another type of reconstruction. Schwarz and colleagues did not find differences in body weight in patients who underwent pouch Roux-en-Y reconstruction versus those without a pouch (14). Ivoven and colleagues compared the pouch with the simple Roux-in-Y reconstruction over a 4-year period and found an equal weight increase between the two groups (15). Another study showed that pouch construction did not significantly improve body weight (19).

Regarding jejunal interposition, an increase in body weight was observed in the studies of Nakane and Adachi. Significant results were reported 12 months after the operation in Nakane's study and throughout the follow-up period in Adachi's study (47).

There was no association between preservation of the duodenal transit and postoperative weight in Fuchs' study (13). Even Ishigami failed to show the superiority of the jejunal interposition over Roux-in-Y in terms of long-term weight gain (21).

\section{Conclusions}

For the prophylaxis of esophago-jejunal reflux the length of the alimentary limb should be at least $50 \mathrm{~cm}$, but not greater than $60 \mathrm{~cm}$ to prevent malabsorption. Quality of life was significantly improved in patients with gastric pouch. Maintaining duodenal transit does not seem to bring any benefit in quality of life, or weight status, even if this is a physiological path. In order to demonstrate the superiority of any reconstruction technique, several studies should be performed on a larger number of patients and with valid instruments for estimating the quality of life.

\section{Conflict of Interest}

The authors declare no conflicts of interests. 


\section{References}

1. Chan A , Wong B, Feldman M, Grover S. Epidemiology of gastric cancer. Uptodate (2019).

2. Prashanth R, Barsouk A. Epidemiology of gastric cancer: global trends, risk factors and prevention. Przeglad gastroenterologiczny. 2019;14.1: 26.

3. Kiyokawa T, Fukagawa T. Recent trends from the results of clinical trials on gastric cancer surgery. Cancer Communications. 2019; 39(1):11.

4. Pavlov R Reconstruction of the gastrointestinal tract after total gastrectomy. Gastroenterol Hepatol Open Access. 2019;10(4): 226-232.

5. Makris E, Poultsides G. A. Surgical considerations in the management of gastric adenocarcinoma. Surgical Clinics, 2017;97(2): 295-316.

6. Chin A C, Espat N J. Total gastrectomy: options for the restoration of gastrointestinal continuity. The Lancet Oncology. 2003;4(5): 271-276.

7. Dorcaratto D, Grande L, Ramon JM, Pera M. Quality of life of patients with cancer of the oesophagus and stomach. Cirugía Española (English Edition). 2011;89(10):635-644.

8. Straatman J, Wielen N, Joosten PJ, Terwee CB, Cuesta MA, Jansma $E P$, et al. Assessment of patient-reported outcome measures in the surgical treatment of patients with gastric cancer. Surgical endoscopy. 2016;30(5):1920-1929.

9. Anderson RT, Aaronson NK, Wilkin D. Critical review of the international assessments of health-related quality of life. Quality of Life Research. 1993;2(6):369-395

10. Qureshi H, Maher M, Ahmed W, Zuberi SJ. Endoscopic ReEvaluation of Visick Grading. Journal Pakistan Medical Association. 1996:46:174-175

11. Troidl H, Kusche J, Vestweber K H, Eypasch E, Maul U. Pouch vs esophagojejunostomy after total gastrectomy: a randomized clinical trial. World journal of surgery. 1987;11(6):699-712.

12. Nakane $\mathrm{Y}$, Okumura S, Akehira K, Okamura S, Boku T, Okusa T, et al. Jejunal pouch reconstruction after total gastrectomy for cancer. A randomized controlled trial. Annals of surgery.1995; 222(1):27.

13. Fuchs KH, Thiede A, Engemann R, Deltz E, Stremme 0, Hamelmann $\mathrm{H}$. Reconstruction of the food passage after total gastrectomy: randomized trial. World journal of surgery. 1995;19(5):698-705.

14. Schwarz A, Beger H G. Gastric substitute after total gastrectomy-clinical relevance for reconstruction techniques. Langenbeck's archives of surgery. 1998;383(6):485-491.

15. livonen MK, Mattila JJ, Nordback IH, Matikainen MJ. Long-term follow-up of thepatientswith jejunal pouchreconstructionafter total gastrectomy. Scand J Gastroenterol. 2000;35:679-85.

16. Nozoe T, Anai H, Sugimachi K. Usefulness of reconstruction with jejunal pouch in total gastrectomy for gastric cancer in early improvement of nutritional condition. The American journal of surgery. 2001;181(3):274-278.

17. Miyoshi K, Fuchimoto S, Ohsaki T, Sakata T, Ohtsuka S, Takakura N. Long-term effects of jejunal pouch added to Roux-en-Y reconstruction after total gastrectomy. Gastric Cancer. (2001);4(3): 156-161.

18. Hoksch B, Ablassmaier B, Zieren J, Müller J M. Quality of Life after Gastrectomy: Longmire's ReconstructionAlone Compared with Additional Pouch Reconstruction. World journal of surgery. 2002; 26(3):335-341.

19. Kono K, lizuka H, Sekikawa T, Sugai H, Takahashi A, Fujii H, et al. Improved quality of life with jejunal pouch reconstruction after total gastrectomy. The American journal of surgery. 2003;185(2):150-154.

20. Adachi S, Inagawa S, Enomoto T, Shinozaki E, Oda T, Kawamoto T. Subjective and functional results after total gastrectomy: prospective study for longterm comparison of reconstruction procedures. Gastric Cancer. 2003;6(1):0024-0029.
21. Ishigami S, Natsugoe S, Hokita S, Aoki T, Kashiwagi H, Hirakawa K, et al. Postoperative long-term evaluation of interposition reconstruction compared with Roux-en-Y after total gastrectomy in gastric cancer: prospective randomized controlled trial. The American journal of surgery. 2011;202(3):247-253.

22. Ito Y, Yoshikawa T, Fujiwara M, Kojima H, Matsui T, Mochizuki Y, et al. Quality of life and nutritional consequences after aboral pouch reconstruction following total gastrectomy for gastric cancer: randomized controlled trial CCG1101. Gastric Cancer. 2016;19(3), 977-985.

23. Zonča, $\mathrm{P}$, Malý $\mathrm{T}$, Innát $\mathrm{P}$, Peteja $\mathrm{M}$, Kraft $\mathrm{O}$, Kuca K. J-pouch versus Roux-en- $Y$ reconstruction after gastrectomy: functional assessment and quality of life (randomized trial). OncoTargets and therapy. 2017;10:13.

24. Noh SM, Bae JS, Jeong HY, Lee BS, Cho JS, Shin K S, et al. Jejunal Interposition after Total Gastrectomy. Journal of the Korean Gastric Cancer Association. 2001;1(4):210-214.

25. Tanaka C, Kanda M, Murotani K, Yoshikawa T, Cho H, Ito Y, et al. Long-term quality of life and nutrition status of the aboral pouch reconstruction after total gastrectomy for gastric cancer: a prospective multicenter observational study (CCOG1505). Gastric Cancer. 2019;22(3):607-616.

26. Pinheiro RN, Mucci S, Zanatto RM, Junior OMP, Bottino A, Fontoura $R$, et al. Quality of life as a fundamental outcome after curative intent gastrectomy for adenocarcinoma: lessons learned from patients. Journal of gastrointestinal oncology. 2019;10(5):989.

27. Barbarisi A, Parisi V, Parmeggiani U, Cremona F, Delrio P. Impact of surgical treatment on quality of life of patients with gastrointestinal tumors. Annals of oncology. 2001;12:S27-S30.

28. Li D, Xu H. The quality of life of gastric cancer patients with and without duodenal passage reconstructions after total gastrectomy. Chinese Journal of Clinical Oncology. 2005; 2(5):810-814.

29. Gertler R, Rosenberg R, Feith M, Schuster T, Friess H. Pouch vs. no pouch following total gastrectomy: meta-analysis and systematic review. American Journal of Gastroenterology. (2009);104(11): 2838-2851.

30. Morita, S, Kaptein A., Oba K, Sakamoto J. The domain structure of the EORTC QLQ-STO22 supported by Japanese validation data. Psycho-Oncology: Journal of the Psychological, Social and Behavioral Dimensions of Cancer. 2008;17(5):474-479.

31. Mochiki E, Kamiyama Y, Aihara R, Nakabayashi T, Kamimura H, Asao $T$, et al. Postoperative functional evaluation of jejunal interposition with or without a pouch after a total gastrectomy for gastric cancer. The American journal of surgery. 2004;187(6):728-735.

32. Zong L, Chen P, Chen $Y$, Shi G. Pouch Roux-en-Y vs No Pouch RouX-en-Y following total gastrectomy: a meta-analysis based on 12 studies. Journal of biomedical research. 2011;25(2):90.

33. Mates IN, Constantinoiu S, Dinu DE. Diversia duodenala în patologia de reflux. Bucuresti: Editura Universitara Carol Davila, 2008.

34. Constantinoiu S. Gastrita si Esofagita alcalina de reflux postoperator. Bucuresti: Editura Daniel T; 1994.

35. Hubens A, Van Hee R, Van Wooren W, Peeters R. Reconstruction of the digestive tract after total gastrectomy. Hepatogastroenterology 1989; 36:18-22

36. Schrock TR, Way LW. Total gastrectomy. Am J Surg. 1978;135: 348-355.

37. Salo JA, Kivilaakso E. Failure of long limb Roux-en-Y reconstruction to prevent alkaline reflux esophagitis after total gastrectomy. Endoscopy 1990;22:65-67.

38. Donovan IA, Fielding JW, Bradby H, Sorgi M, Harding LK. Bile diversion after total gastrectomy. Br J Surg. 1982;69:389-390.

39. Hoya Y, Mitsumori N, Yanaga K. The advantages and disadvantages of a Roux-en-Y reconstruction after a distal gastrectomy for gastric cancer. Surg Today 2009;39:647-651.

40. Choban PS, Flancbaum L. The effect of Roux limb lengths on outcome after Roux-en-Y gastric bypass: a prospective, randomized clinical trial. Obes Surg. 2002;12:540-5. 
41. Matei D, Dadu R, Prundus R, Danci I, Ciobanu L, Mocan T, et al. Alkaline reflux esophagitis in patients with total gastrectomy and Roux en $Y$ esojejunostomy. Journal of Gastrointestinal \& Liver Diseases. 2010;19(3).

42. Rea T, Bartolacci M, Leombruni E, Brizzi F, Picardi N. Study of the antireflux action of the Roux-en-Y jejunal loop in reconstruction after gastrectomy and nutritional status in the follow-up. Ann Ital Chir 2005:76:343-351.

43. Inabnet WB, Quinn T, Gagner M, et al. Laparoscopic Roux-en-Y gastric bypass in patients with $\mathrm{BMI}<50$ : a prospective randomized trial comparing short and long limb lengths. Obes Surg. 2005; 15:51-7.

44. Nergaard BJ, Leifsson BG, Hedenbro J, Gislason H. Gastric bypass with long alimentary limb or long pancreato-biliary limb - longterm results on weight loss, resolution of co-morbidities and metabolic parameters. Obesity surgery. 2014;24(10):1595-1602.

45. Seetharam P, Rodrigues G. Short bowel syndrome: a review of management options. Saudi journal of gastroenterology: official journal of the Saudi Gastroenterology Association, 2011;17(4), 229.

46. Park KB, Park JY, Lee S, Kwon O, Chung HY, Yu W. Impact of body mass index on the quality of life after total gastrectomy for gastric cancer. Cancer research and treatment: official journal of Korean Cancer Association. 2018:50(3):852.

47. Lehnert T, Buhl K. Techniques of reconstruction after total gastrectomy for cancer. British journal of surgery. 2004;91(5):528-539. 